\title{
Molecular detection of Turnip yellows virus (TuYV) infecting alfalfa in Iran
}

\author{
Shirin Farzadfar ${ }^{1} \cdot$ Reza Pourrahim $^{1}$
}

Received: 15 December 2016 / Accepted: 19 February 2017 / Published online: 23 February 2017

(C) Australasian Plant Pathology Society Inc. 2017

\begin{abstract}
Symptomatic alfalfa leaf samples were collected from Western Iran. RT-PCR was performed using degenerate primers resulting in amplification of a fragment approximately $600 \mathrm{bp}$ in size corresponding to the coat protein (CP) gene of luteoviruses. BLAST analysis of the CP nucleotide sequences revealed the highest similarity (96-97\%) with Turnip yellows virus (TuYV) isolates. The present study shows for the first time the occurrence of TuYV in Iran.
\end{abstract}

Keywords Alfalfa · Iran · Turnip yellows virus

Turnip yellows virus (TuYV) of the Polerovirus genus, family Luteoviridae has a wide host range and experimentally can infect species from at least 13 plant families, including many species of economic importance belonging to Brassicaceae, Chenopodiaceae, Asteraceae and Fabaceae. The wide range of cultivated plants and weed species susceptible to TuYV increases the number of potential reservoir hosts in which the virus can survive throughout the winter and provide an inoculum source for future virus outbreaks (Latham et al. 2003). TuYV is vectored by several aphid species in a persistent manner with the main vector being the peach-potato aphid, Myzus persicae (Hauser et al. 2002). TuYV is the

Electronic supplementary material The online version of this article (doi:10.1007/s13314-017-0236-7) contains supplementary material, which is available to authorized users.

Shirin Farzadfar

farzadfar2002@yahoo.com

1 Plant Virus Research Department, Iranian Research Institute of Plant Protection (IRIPP), Agricultural Research, Education and Extension Organization (AREEO), P.O.Box 19395-1454, Tehran, Iran causative agent of an important disease in oilseed rape (Brassica napus), resulting in seed yield losses of approximately $0.3 \mathrm{t} / \mathrm{ha}$ and decreasing oil yield by $13.4 \%$ (Smith and Hinckes 1985).

Alfalfa (Medicago sativa) is the most cultivated forage legume in the world and is native to a warm temperate climate such as Iran, where it is thought to have originated (Karimi 1990). Alfalfa is planted on areas exceeding 640,000 ha in Iran under different climate conditions (Anonymous 2014) and is affected by a wide range of pathogens including viruses. Some important luteoviruses such as Been leaf roll virus (BLRV) (Rahman and Peaden 1993), Beet western yellows virus (BWYV) and Soybean dwarf virus (SbDV) (Haj Kassem et al. 2001; Jones 2004) have been reported to infect alfalfa. Among these, BLRV and SbDV have been reported from alfalfa in Iran (Behjatnia and Izadpanah 1993; Faraji et al. 2012). This study was performed to assess the presence of TuYV infecting alfalfa in Western Iran, the most important forage legume cultivation area in the country. The identification of TuYV isolate in the major alfalfa growing areas is important for developing effective control strategies both in alfalfa and other hosts.

Symptomatic alfalfa leaf samples showing yellowing, reddening, leaf and stem necrosis and stunting were collected from Western Iran. Total RNA was extracted from leaf samples using Tri-reagent (Sigma, St. Louis, Mo, USA) according to the manufacturer's instructions. Two sets of degenerate primers designed to amplify a DNA fragment in luteoviruses' CP gene (Abraham et al. 2006, 2008) were used for reverse transcription-polymerase chain reaction (RT-PCR). The first set included a combination of a sense primer $\mathrm{S} 1$ and antisense primer AS3 expected to flank the whole coat protein gene of all known legume poleroviruses (Abraham et al. 2006), but not SbDV and BLRV, since S1 does not adequately match their sequences. The second set was a combination of the 
sense primer S2 with the antisense primer AS3, that is expected to amplify a product of ca. 340 bases of the C-terminal part of the $\mathrm{CP}$ gene of all known legume luteoviruses including BLRV and SbDV (Abraham et al. 2008). First, single-strand cDNA was synthesised using $10 \mu \mathrm{l}$ of template RNA $(1.5 \mu \mathrm{g})$, one $\mu \mathrm{l}$ of the antisense primer AS3 (20 pmol/ $\mu \mathrm{l}), 2 \mu \mathrm{l}$ of $10 \mathrm{X}$ RT-buffer, and one $\mu$ l of RevertAidTM M-MuLV reverse transcriptase (200 unit/ $\mu$ l) (Fermentas, Vilnius, Lithuania) in $20 \mu \mathrm{l}$ reaction volume at $42{ }^{\circ} \mathrm{C}$ for $60 \mathrm{~min}$ and then at $72{ }^{\circ} \mathrm{C}$ for $10 \mathrm{~min}$ to inactivate the enzyme, according to manufacturer's instructions. For PCR amplification in $50 \mu \mathrm{l}$ reaction volumes, $0.2 \mu \mathrm{l}$ of each primer $(20 \mathrm{pmol} / \mu \mathrm{l}), 5 \mu \mathrm{l}$ of $10 \mathrm{X} \mathrm{Pfu}$ reaction buffer, $1.5 \mu \mathrm{l} \mathrm{MgCl} 2(50 \mathrm{mM}), 1 \mu \mathrm{ldNTPs}(10 \mathrm{mM})$ and 2.5 unit $P f u$ DNA polymerase (SinaClon, Tehran, Iran) were added to each $5 \mu$ l of first strand cDNA reaction mixture. Cycle conditions were the following: $95{ }^{\circ} \mathrm{C}$ for $5 \mathrm{~min}$ and followed by 35 cycles at $95{ }^{\circ} \mathrm{C}$ for $1 \mathrm{~min}, 48{ }^{\circ} \mathrm{C}$ for $1 \mathrm{~min}$, and $72{ }^{\circ} \mathrm{C}$ for $2 \mathrm{~min}$. After electrophoresis, PCR products close to the expected size of ca. $600 \mathrm{bp}$ were obtained using primer pair S1 and AS3 for 51 out of 55 RNA samples investigated. No clear differences were observed between the sizes of PCR products of alfalfa leaf extracts. No DNA amplification was observed by using the S2 and AS3 primer pair.

The expected PCR products corresponding to the CP gene of six Iranian isolates were excised from the gel, cleaned by the QIAquick Gel Extraction Kit (QIAGEN, Valencia, CA, USA), cloned into a pGEM-T Easy vector (Promega, Madison, WA, USA) and transferred by heat shock into
Fig. 1 A phylogenetic tree using complete coat protein $(\mathrm{CP})$ nucleotide sequences of Turnip yellows virus isolates constructed by the $\mathrm{NJ}$ algorithm implemented in MEGA 5 (Tamura et al. 2011). Bootstrap values (1000 replicates) are given at the branch nodes

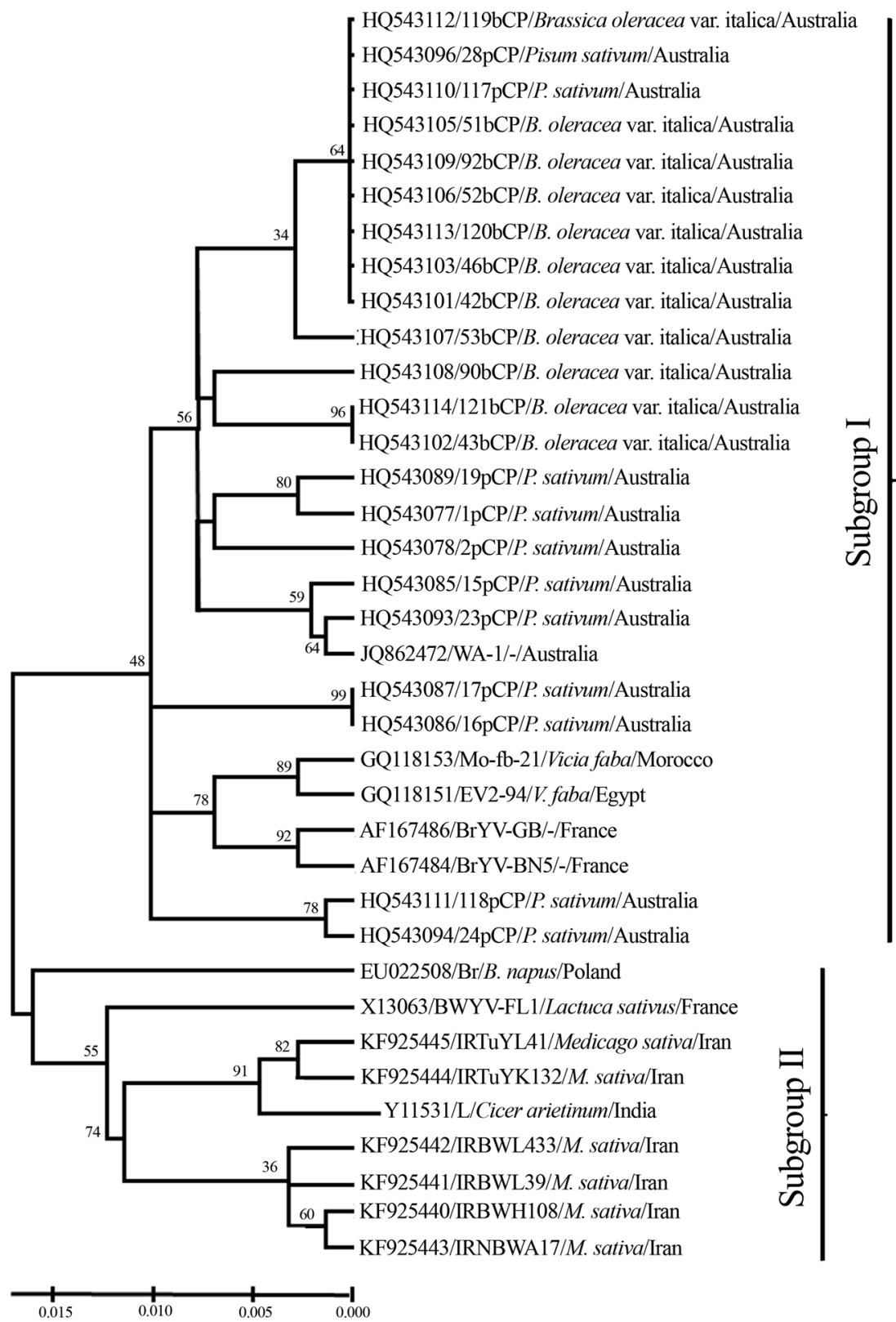


DH5 $\alpha$ competent Escherichia coli cells according to the kit's manufacturers' instructions. Nucleotide sequences from each isolate were determined using cloned DNAs, and also RTPCR products. DNA sequencing was done in both directions with dideoxy sanger method by PGGene Company (www. pggene.ir). Sequence data were edited and assembled using BIOEDIT version 5.0.9 (Hall 1999). The complete CP nucleotide sequence of six Iranian TuYV isolates consisted of 609 nt with a deduced protein product of 202 amino acids (aa) in size. BLAST search of the CP nucleotide sequences for the Iranian isolates H108, L433, L39 and A17, showed about 96 $\%$ identity with a French TuYV isolate (Accession number X13063) (de Miranda et al. 1995), whereas about 97\% identity was found for the Iranian isolates L41 and K132 with an Indian isolate (Accession number Y11531).

The virus population structure and their genetic diversity are important factors to the development of efficient control measures for viruses. The CP nucleotide sequences of six Iranian TuYV isolates obtained in this study and those of 30 TuYV isolates from GenBank were used for sequence alignment. Details of the isolates, their names and origin are shown in Supplementary Table S1. For optimal alignment the CP amino acids sequences were aligned using CLUSTAL X2 (Larkin et al. 2007) with Transalign (kindly supplied by George Weiller, Australian National University, Canberra, Australia). After all gaps and nucleotides homologous to them had been removed from the aligned sequences, a phylogenetic tree was inferred using the Neighbor-Joining (NJ) method implemented in MEGA 5 (Tamura et al. 2011). The phylogenetic tree indicated that TuYV isolates clustered into two subgroups (subgroupI and subgroupII). All of the Australian isolates, two isolates from France (BrYV-GB and BrYV-BN5) and isolates from Morocco (Mo-fb-21) and Egypt (EV2-94) clustered in subgroup I. The Iranian TuYV isolates fell into subgroup II with a French (FL1), Polish (Br) and an Indian isolate (L) (Fig. 1). Overall CP nucleotide identity between TuYV isolates ranged from $85.0 \%$ to $100.0 \%$. Comparative sequence analysis revealed that isolates in subgroup I shared the highest nucleotide sequence identity (90.2 to $100.0 \%$ ), and the lowest nucleotide sequence identity indicated for subgroup II (90.2 to $85.0 \%)$. Analysis of the CP nucleotide sequence revealed a 96-99.2\% nucleotide identity (95.5-99.5\% at amino acid level) between the Iranian TuYV isolates (Supplementary Fig. 1).

Alfalfa can provide an inoculum reservoir and are hence of particular significance in the epidemiology of viruses. Based on previous studies, sugar beet (Beta vulgaris), oilseed rape and Chenopodium capitatum could be used as indicator plants to distinguish between Beet mild yellowing virus (BMYV) and BWYV European isolates (renamed TuYV) (Hauser et al. 2000). Our preliminary results of host range studies showed that an Iranian TuYV isolate could infect different brassica species but not beet. This result is consistent with those previously reported by other researchers (Stevens et al. 1994; Hauser et al. 2000). Iranian TuYV isolates also induced systemic chlorosis and yellowing on alfalfa plants inoculated by aphids.

After the classification of TuYV and BWYV as different virus species, it was shown that some part of these BWYV detections actually corresponded to TuYV (based on the published data). BWYV has been previously reported from Iran (Makkouk et al. 2003; Shahraeen et al. 2003). However, according to the previous reports, identification of TuYV in Iran could not be ascertained and the present study shows clearly for the first time the occurrence of TuYV in Iran. Despite using insecticides in annual crops (especially against aphids), less or no insecticides are used for vector control in lucerne. As a consequence, most aphids migrate between annually crops and alfalfa fields, which may increase viral spread (van Leur and Kumari 2011). Generally the significance of $M$. sativa in the economy illustrates the importance of gathering information on viral spread and subsequent crop losses. Therefore an extension of survey may be helpful to reveal the presence of more viruses and viral strains.

\section{References}

Abraham AD, Menzel W, Lesemann DE, Varrelmann M, Vetten HJ (2006) Chickpea chlorotic stunt virus: a new polerovirus infecting cool season food legumes in Ethiopia. Phytopathology 96:437-446

Abraham AD, Varrelmann M, Vetten HJ (2008) Molecular evidence for the occurrence of two new luteoviruses in cool season food legumes in Northeast Africa. African J Biotech 7:414-420

Anonymous (2014) A statistical glance at 2011 agriculture in Iran (Statistics and Information Technology Office) pp 77

Behjatnia SAA, Izadpanah K (1993) Purification, serology and natural hosts of the Bean leaf roll virus in Iran. Iranian J Plant Pathol 29:43

de Miranda JR, Stevens M, De Bruyne E, Smith HG, Bird C, Hull R (1995) Sequence comparison and classification of beet luteovirus isolates. Arch Virol 140:2183-2200

Faraji K, Farzadfar S, Maleki M, Pourrahim R (2012) Report of Soybean dwarf virus-SbDV infection in alfalfa fields of Lorestan province. Proceedings of the 20th Iranian Plant Protection Congress, 25-28 August, Shiraz University, Shiraz, Iran

Haj Kassem AA, Makkouk KM, Attar N (2001) Viruses on cultivated forage legumes in Syria. Arab J Plant Protect 19:73-79

Hall TA (1999) BIOEDIT: a user-friendly biological sequence alignment editor and analysis program for windows 95/98/NT. Nuc Acids Symp Ser 41:95-98

Hauser S, Stevens M, Beuve M, Lemaire O (2002) Biological properties and molecular characterization of Beet chlorosis virus $(\mathrm{BChV})$. Arch Virol 147:745-762

Hauser S, Stevens M, Mougel C, Smith HG, Fritsch C, Herrbach E, Lemaire O (2000) Biological, serological and molecular variability suggest three distinct beet polerovirus species. Phytopathology 90 : 460-466

Jones RAC (2004) Occurrence of virus infection in seed stocks and 3year old pastures of lucerne (Medicago sativa). Australian J Agric Res 55:757-764

Karimi H (1990) Alfalfa. Tehran University Publication Center, Tehran, $371 \mathrm{pp}$ 
Larkin MA, Blackshields G, Brown NP et al (2007) Clustal wand Clustal $X$ version 2.0. Bioinformatics 23:2947-2948

Latham LJ, Smith LJ, Jones RAC (2003) Incidence of three viruses in vegetable brassica plantings and associated wild radish weeds in south-West Australia. Australasian Plant Pathol 32:387-391

Makkouk KM, Kumari SG, Shahraeen N, Fazlali Y, Farzadfar S, Ghotbi T, Mansouri AR (2003) Identification and seasonal variation of viral diseases of chickpea and lentil in Iran. J Plant Dis Protec 110:157-169

Rahman F, Peaden RN (1993) Incidence of viruses on alfalfa in western North America. Plant Dis 77:160-162

Shahraeen N, Farzadfar S, Lesemann DE (2003) Incidence of viruses infecting winer oilseed rape (Brassica napus ssp. oleifera) in Iran. J Phytopath 151:614-616
Smith HG, Hinckes JA (1985) Studies on Beet western yellows virus in oilseed rape (Brassica napus ssp. oleifera) and sugar beet (Beta vulgaris). Ann Appl Boil 107:473-484

Stevens M, Smith HG, Hallsworth PB (1994) The host-range of beet yellowing viruses among common arable weed species. Plant Pathol 43:579-588

Tamura K, Peterson D, Peterson N, Stecher G, Nei M, Kumar S (2011) MEGA5: molecular evolutionary genetics analysis using maximum likelihood, evolutionary distance, and maximum parsimony methods. Mol Biol Evol 28:2731-2739

van Leur JAC, Kumari SG (2011) A survey of lucerne in northern new South Wales for viruses of importance to the winter legume industry. Australasian Plant Pathol 40:180-186 